\title{
A Survey of Data Base Management in Enhancing the Work Performance of Office Technology and Management Graduates in Selected Organisation in Abuja
}

\author{
Shamsu Shehu ${ }^{1}$, Fatima Aminu ${ }^{2}$ \\ Al-qalam University Katsina
}

\begin{abstract}
The research provides a survey of data base management in enhancing the work performance of Office Technology Management graduates in selected organization in Abuja. It provides a conceptual and theoretical appraisal of data base management and its significance in enhancing the work performance of Office Technology and Management graduates.
\end{abstract}

Keywords: office technology, management, survey, evaluation

\section{Background}

In the early days of computerization, it was normal to maintain specific files for individual applications. Data were processes centrally in batches and there was little or no online interrogation of data. This approach is wholly inefficient for most of today's data processing systems. Supporting this, Vossen (1991) enumerated the problems that result from organizing data using the file system:

1) There exists a high redundancy between files, which result from the fact that the information is replicated in different places, and that these replications are not controlled by a central monitor.

2) Inconsistencies might result from the possibilities that a program makes changes on the files it uses without these changes being made (at the same time) by all other programs that uses the file.

3) There exists inflexibility against changes in the application: if new actions or events arise in the course of time, these can be realised at a substantial expense of time.

4) The work of many programmers involved is characterised by low productivity, since program maintenance is expensive: if the structure of an existing file has to be modified during its lifetime, then all application programs has to be modified correspondingly.

To overcome these problems, databases were developed. It is now common for large organisations to organise their operational data using the database technology. The subject of database is adequately covered in many works on database technology. Clifton (1983) briefly defines database as a collection of data supporting the operation of an organization. Quoting CIMA, Lucey (1991) provides a more detailed definition:A database is a file of data structured in such a way that it may serve a number of applications without its structure being dictated by any one of those applications, the concepts being that programs are written round the database rather than files being structured to meet the needs of particular programs.
A database is an organized collection of data. The data is typically organized to model relevant aspects of reality (for example, the availability of rooms in hotels), in a way that supports processes requiring this information (for example, finding a hotel with vacancies).

A general-purpose database management system (DBMS) is a software system designed to allow the definition, creation, querying, update, and Administration of database: Wellknown DBMSs include MySQL, PostgreSQL, SQLite, Microsoft SQL Server, Microsoft Access, Oracle, Sybase, DBASE, FoxPro, and IBM DB2. A database is not generally portable across different DBMS, but different DBMSs can inter-operate by using standards such as SQL and ODBC or JDBC to allow a single application to work with more than one database.

Russell, M. (1987) dealt extensively on the need for the use of computers on such database system like computerized clearance system. In the words of Dim Orji (2003).

Advances in technology are rapidly changing today's modern business around the globe and have seriously affected every aspect of the office. The effects are generally felt in science, commerce, industry, education, politics, and particularly in the business world. These new technologies have facilitated new business procedures from the traditional office of yester years to the electronic office. Nwogwugwu (2002) asserted that the introduction of sophisticated telecommunication equipment, computer and word processors, information technology machines coupled with the new management techniques have changed old work habits, thereby resulting in complete job re-designation and acquisition of new skills.

Osuala (1998) observed that the most common office equipment before the office revolution were typewriters, telephones and filing cabinets. All these provide the means by which the three main information activities are carried out - namely document production, communication and filing. During that time office work was dull, slow and labour intensive. According to Osuala, these three 


\section{International Journal of Science and Research (IJSR) \\ ISSN (Online): 2319-7064}

Index Copernicus Value (2015): 78.96 | Impact Factor (2015): 6.391

traditional technologies are still very much part of office life, but the electronic office has introduced a number of innovations which complemented or replaced them. Etonyeaku (2009) noted that secretaries in the organizations of yester years were dealing with papers worked with manual machines, relied on postal services for external communications and kept office records in the cabinets. These technological innovations demand new skills, attitudes and the development of new professional and intellectual concepts among secretaries.

Harvey (1986) noted that since the primary business of the modern office is to collect, record, sort, analyze, store and distribute information, office information system (OIS) integrates all available hardware, software procedures and human resources so that office information is not only processed accurately, speedily and comprehensively by also made available when, where, and in the manner required.

The emphasis in the new Office Technology and Management curriculum, according to Esene (2011) is to radically shift from where the profession has been in order to join the rest of the developed countries. Some discoveries in the Office Technology and Management profession have shown that gone are the days when secretaries were traditionally regarded as office assistants to their bosses who sit behind the typewriters. The story is changing very fast as today's secretaries trained with modern office automation, materials and equipment are expected to cope with all the changes occasioned by ICT driven arrangements.

The modern offices of today, lay due emphasis on paperless office as a way of facilitating the process of correspondence handling and operation. For instance, Ekula (2008) stated that in offices, computer, database management and other accessories are increasingly being used to organize and control records. Secretaries are now being required to be able to operate computers using Dbase, Excel, Corel Draw and Word Processing packages such as Word perfect, Ms Word, Ms Power point, Adobe Page maker and in particular the dexterity to use most of the application packages contained in Windows 2000 to 2007 respectively.

\section{Problem Statement}

At this era of information age, and the age of global village there is a need to make things computerized like filing system so that the Office technology and management graduates can make their work more expedient and easier.

There exists a high redundancy between files, inconsistencies might result, there exists inflexibility against changes in the application and there is the problem of adopting and maintaining standards.
It is observed that Office Technology and Management graduates are not improved in their work performance in various organizations which lead to this research, another problem that emerged here was that they lack the required skills needed from them by their employer in the organization. Communication Technology to the Office Technology and Management graduates, but there were not empirical evidence in literature available to the researcher which shows whether database management can enhance the work performance of Office Technology and Management graduates in organizations. This unsatisfactory state of affairs created a gap in the body of knowledge which this study has to fill.

\section{General objective}

The main rationale behind this research is to provide a survey of Database Management in enhancing the work performance of office technology and management graduates in Abuja.

\section{Specific objectives}

The specific objective of the study were to:

1) To examine the impact of database management in enhancing the work performance of Office Technology and Management graduates.

2) To assess the extent to which database management can enhance the work performance of Office Technology and Management graduates.

3) To provide a survey of the significance of database management in enhancing the work performance of Office Technology and Management graduates.

4) To suggest an improved method of enhancing better services using database.

\section{Methodology}

Questionnaire is the main research instrument used for the study to gather necessary data from the samplerespondents. The questionnaire was distributed to some secretarial/office staff in some selected organizations in Abuja.

The questionnaire is structured type and provides answers to the research questions.

This instrument is divided and limited into two sections; Section A and B. Section A deals with the personal data of the respondents while Section B contains research statement postulated in line with the research question in chapter one. Options or alternatives are provided for each respondent to pick or tick one of the options.

\section{Analysis and interpretation}




\section{International Journal of Science and Research (IJSR) \\ ISSN (Online): 2319-7064 \\ Index Copernicus Value (2015): 78.96 | Impact Factor (2015): 6.391}

Table 1: Distribution of respondents by Gender, Age range, institution attended, education qualification, Office Technology and Management experience, level of competence, first impression about the interface design, the type of database application software prepare, type of activities perform with database and How will you rate your responsibility or task in our organization without using a database.

\begin{tabular}{|c|c|c|}
\hline Factor & Category & Percentage \\
\hline Gender & $\begin{array}{l}\text { Male } \\
\text { Female }\end{array}$ & $\begin{array}{l}61.30 \\
38.70\end{array}$ \\
\hline Age_range & $\begin{array}{l}\text { under } 18 \\
\text { Adult }\end{array}$ & $\begin{aligned} 5.40 \\
94.60\end{aligned}$ \\
\hline Institution attended & $\begin{array}{c}\text { University } \\
\text { Polytechnic } \\
\text { College of education }\end{array}$ & $\begin{array}{l}43.00 \\
44.10 \\
12.90\end{array}$ \\
\hline Education qualification & $\begin{array}{c}\text { BSC secretarial studies } \\
\text { HND secretarial studies } \\
\text { NCE secretarial studies } \\
\text { ND secretarial studies } \\
\text { Others }\end{array}$ & $\begin{array}{c}24.70 \\
33.30 \\
7.50 \\
6.50 \\
28.00\end{array}$ \\
\hline office technology and management experience & $\begin{array}{c}\text { Less than } 1 \\
1-5 \text { years } \\
6-10 \text { years } \\
\text { Greater than } 10 \\
\end{array}$ & $\begin{array}{l}12.90 \\
48.40 \\
23.70 \\
15.10\end{array}$ \\
\hline $\begin{array}{l}\text { Level of competence in office technology and } \\
\text { management }\end{array}$ & $\begin{array}{l}\text { Very high } \\
\text { High } \\
\text { Moderate } \\
\text { Low } \\
\end{array}$ & $\begin{array}{c}30.10 \\
44.10 \\
21.50 \\
4.30 \\
\end{array}$ \\
\hline $\begin{array}{l}\text { What is your first impression about the } \\
\text { interface design in database? }\end{array}$ & $\begin{array}{l}\text { Excellent } \\
\text { Very good } \\
\text { Good } \\
\text { Poor }\end{array}$ & $\begin{array}{c}32.30 \\
37.60 \\
25.80 \\
4.30\end{array}$ \\
\hline $\begin{array}{c}\text { what type of database application software do } \\
\text { you prepare }\end{array}$ & $\begin{array}{l}\text { Standalone database situated in one computer but can be } \\
\text { remotely access over a local area network } \\
\text { Hosted base situated in a computer that can be remotely } \\
\text { access over the internet }\end{array}$ & 29.00 \\
\hline $\begin{array}{c}\text { What type of activities do you normally } \\
\text { perform with your database? }\end{array}$ & $\begin{array}{c}\text { Data entry } \\
\text { Query } \\
\text { Controlling of user privilege }\end{array}$ & $\begin{array}{l}34.40 \\
47.30 \\
18.30\end{array}$ \\
\hline $\begin{array}{l}\text { How will you rate your responsibility or task in } \\
\text { our organization without using a database }\end{array}$ & $\begin{array}{l}\text { Long } \\
\text { Medium } \\
\text { short }\end{array}$ & $\begin{array}{c}9.70 \\
34.40 \\
55.90\end{array}$ \\
\hline
\end{tabular}

Table2: Interpretation of mean based on four point likert scale

\begin{tabular}{|c|c|}
\hline Mean & Interpretation of the mean \\
\hline mean $>=3.5$ & Strongly Agree \\
\hline $3.5>=2.5$ & Agree \\
\hline $2.5>=1.5$ & Disagree \\
\hline $1.5>=0.5$ & Strongly Disagree \\
\hline
\end{tabular}

Table 3: Result of the analysis

\begin{tabular}{|c|c|c|c|c|c|c|}
\hline S/No & Statement & $\begin{array}{c}4 \\
\text { Strongly } \\
\text { Agree }\end{array}$ & 3 Agree & $\begin{array}{c}2 \\
\text { Disagree }\end{array}$ & $\begin{array}{c}1 \\
\text { Strongly } \\
\text { Disagree }\end{array}$ & $\begin{array}{c}\text { WA } \\
\text { (Mean) }\end{array}$ \\
\hline 1 & you need database management in your organization & $\begin{array}{c}48 \\
\mathbf{( 5 1 . 6 0 )}\end{array}$ & $\begin{array}{c}38 \\
(\mathbf{4 0 . 9 0 )}\end{array}$ & $\begin{array}{c}6 \\
(6.50)\end{array}$ & $\begin{array}{c}1 \\
(\mathbf{1 . 1 0})\end{array}$ & 3.43 \\
\hline 2 & $\begin{array}{l}\text { Database management improve your record keeping and data } \\
\text { processing when you are discharging your responsibility }\end{array}$ & $\begin{array}{c}49 \\
\mathbf{( 5 2 . 7 0 )} \\
\end{array}$ & $\begin{array}{c}36 \\
(38.70) \\
\end{array}$ & $\begin{array}{c}7 \\
(7.50) \\
\end{array}$ & $\begin{array}{c}1 \\
(\mathbf{1 . 1 0})\end{array}$ & 3.43 \\
\hline 3 & $\begin{array}{c}\text { Database can provide a referential integrity of data for } \\
\text { sensitive record generation }\end{array}$ & $\begin{array}{c}39 \\
\mathbf{( 4 1 . 9 0 )}\end{array}$ & $\begin{array}{c}46 \\
(\mathbf{4 9 . 5 0 )}\end{array}$ & $\begin{array}{c}7 \\
(7.50)\end{array}$ & $\begin{array}{c}1 \\
(\mathbf{1 . 1 0})\end{array}$ & 3.32 \\
\hline 4 & $\begin{array}{c}\text { Using query language makes retrieval of data/information } \\
\text { easier }\end{array}$ & $\begin{array}{c}47 \\
\mathbf{( 5 0 . 5 0 )}\end{array}$ & $\begin{array}{c}40 \\
(\mathbf{4 3 . 0 0})\end{array}$ & $\begin{array}{c}5 \\
(5.40)\end{array}$ & $\begin{array}{c}1 \\
(\mathbf{1 . 1 0})\end{array}$ & 3.43 \\
\hline 5 & $\begin{array}{l}\text { It is suitable to store data/information using database } \\
\text { management }\end{array}$ & $\begin{array}{c}44 \\
(\mathbf{4 7 . 3 0})\end{array}$ & $\begin{array}{c}39 \\
(\mathbf{4 1 . 9 0 )}\end{array}$ & $\begin{array}{c}9 \\
(9.70)\end{array}$ & $\begin{array}{c}1 \\
(\mathbf{1 . 1 0})\end{array}$ & 3.35 \\
\hline 6 & $\begin{array}{c}\text { The use of database management makes work become easy } \\
\text { and efficient }\end{array}$ & $\begin{array}{c}56 \\
\mathbf{( 6 0 . 2 0 )}\end{array}$ & $\begin{array}{c}30 \\
(32.30)\end{array}$ & $\begin{array}{c}6 \\
(6.50)\end{array}$ & $\begin{array}{c}1 \\
(\mathbf{1 . 1 0})\end{array}$ & 3.52 \\
\hline 7 & $\begin{array}{l}\text { Database management in organizations improves } \\
\text { organizational effectiveness of the secretarial duties }\end{array}$ & $\begin{array}{c}40 \\
\mathbf{( 4 3 . 0 0 )}\end{array}$ & $\begin{array}{c}45 \\
(\mathbf{4 8 . 4 0 )} \\
\end{array}$ & $\begin{array}{c}7 \\
(7.50)\end{array}$ & $\begin{array}{c}1 \\
(\mathbf{1 . 1 0})\end{array}$ & 3.33 \\
\hline 8 & $\begin{array}{l}\text { Office technology and management is all about office } \\
\text { management and database management will enable secretaries }\end{array}$ & $\begin{array}{c}30 \\
(\mathbf{3 2 . 3 0}) \\
\end{array}$ & $\begin{array}{c}52 \\
(\mathbf{5 5 . 9 0 )} \\
\end{array}$ & $\begin{array}{c}11 \\
(\mathbf{1 1 . 8 0})\end{array}$ & $\begin{array}{c}0 \\
(\mathbf{0 . 0 0})\end{array}$ & 3.21 \\
\hline
\end{tabular}

\section{Volume 6 Issue 7, July 2017 www.ijsr.net}

Licensed Under Creative Commons Attribution CC BY 


\section{International Journal of Science and Research (IJSR) \\ ISSN (Online): 2319-7064}

Index Copernicus Value (2015): 78.96 | Impact Factor (2015): 6.391

\begin{tabular}{|c|c|c|c|c|c|c|}
\hline & to manage office at work places & & & & & \\
\hline 9 & $\begin{array}{l}\text { Office technology and management should focus well on } \\
\text { database management for better performance at work place }\end{array}$ & $\begin{array}{c}37 \\
(39.80) \\
\end{array}$ & $\begin{array}{c}46 \\
(\mathbf{4 9 . 5 0 )} \\
\end{array}$ & $\begin{array}{c}9 \\
(9.70)\end{array}$ & $\begin{array}{c}1 \\
(1.10)\end{array}$ & 3.28 \\
\hline 10 & $\begin{array}{c}\text { The work of office technology and management graduates in } \\
\text { organisation is very significant }\end{array}$ & $\begin{array}{c}37 \\
(39.80)\end{array}$ & $\begin{array}{c}46 \\
(\mathbf{4 9 . 5 0 )}\end{array}$ & $\begin{array}{c}9 \\
(9.70)\end{array}$ & $\begin{array}{c}1 \\
(\mathbf{1 . 1 0})\end{array}$ & 3.28 \\
\hline 11 & $\begin{array}{c}\text { You can rise to the most covetous positions in organizations } \\
\text { with the use of database management }\end{array}$ & $\begin{array}{c}33 \\
(\mathbf{3 5 . 5 0})\end{array}$ & $\begin{array}{c}49 \\
\mathbf{( 5 2 . 7 0 )}\end{array}$ & $\begin{array}{c}10 \\
(\mathbf{1 0 . 8 0})\end{array}$ & $\begin{array}{c}1 \\
(\mathbf{1 . 1 0})\end{array}$ & 3.23 \\
\hline
\end{tabular}

From the tableabove; in Question 1, 51.60\% of the respondent strongly agrees, $40.90 \%$ agree, $6.50 \%$ disagree and $1.10 \%$ strongly disagree that they need database management in your organizationThe mean average is 3.43 $(3.43>=2.5)$ which agrees they need database management in their organisations.

Question 2, 52.70\% of the respondent strongly agrees 38.70 $\%$ agree, $7.50 \%$ disagree, and $1.10 \%$ strongly disagree that Database management improve your record keeping and data processing when you are discharging your responsibility. The mean average is $3.43(3.43>=2.5)$ which agrees that Database management improve your record keeping and data processing when you are discharging your responsibility.

Question 3, 41.90\% of the respondent strongly agrees, $49.50 \%$ agree, $7.50 \%$ disagree, and $1.10 \%$ strongly disagree that Database can provide a referential integrity of data for sensitive record generation. The mean average is 3.32 $(3.32>=2.5)$ which agrees Database can provide a referential integrity of data for sensitive record generation.

Question 4, 50.50\% of the respondent strongly agrees, $43.00 \%$ agree, $5.40 \%$ disagree, and $1.10 \%$ strongly disagree that Using query language makes retrieval of data/information easier. The mean average is 3.43 (3.43>= 2.5) which agrees that Using query language makes retrieval of data/information easier.

Question 5, 47.30\% of the respondent strongly agrees, $41.90 \%$ agree, $9.70 \%$ disagree, and $1.10 \%$ strongly disagree that it is suitable to store data/information using database management. The mean average is $3.35(3.35>=2.5)$ which agrees that It is suitable to store data/information using database management.

Question 6, 60.20\% of the respondent strongly agrees, $32.30 \%$ agree, $6.50 \%$ disagree, and $1.10 \%$ strongly disagree that the use of database management makes work become easy and efficient. The mean average is $3.52(3.52>=2.5)$ which agrees that the use of database management makes work become easy and efficient.

Question 7, 43.00\% of the respondent strongly agrees $48.40 \%$ agree, $7.50 \%$ disagree, and $1.10 \%$ strongly disagree that Database management in organisations improves organizational effectiveness of the secretarial duties. The mean average is $3.33(3.33>=2.5)$ which agrees that Database management in organisations improves organizational effectiveness of the secretarial duties.

Question 8, 32.30\% of the respondent strongly agrees, $55.90 \%$ agree, $11.80 \%$ disagree, and $1.10 \%$ strongly disagree that Office technology and management is all about office management and database management will enable secretaries to manage office at work places. The mean average is $3.21(3.21>=2.5)$ which agrees that Office technology and management is all about office management and database management will enable secretaries to manage office at work places.

Question 9, 39.80\% of the respondent strongly agrees $49.50 \%$ agree, $9.70 \%$ disagree, and $1.10 \%$ strongly disagree that Office technology and management should focus well on database management for better performance at work place. The mean average is $3.282(3.28>=2.5)$ which agrees that Office technology and management should focus well on database management for better performance at work place.

Question 10, 39.80\% of the respondent strongly agrees, $49.50 \%$ agree, $9.70 \%$ disagree, and $1.10 \%$ strongly disagree that the work of office technology and management graduates in organisation is very significant. The mean average is $3.28(3.28>=2.5)$ which agrees that The work of office technology and management graduates in organisation is very significant.

Question 11, 35.50\% of the respondent strongly agrees, $52.70 \%$ agree, $10.80 \%$ disagree, and $1.10 \%$ strongly disagree that they can rise to the most covetous positions in organizations with the use of database management. The mean average is $3.23(3.23>=2.5)$ which agrees that they can rise to the most covetous positions in organizations with the use of database management.

\section{Conclusion}

A survey was conducted to identify the issues at possible way of improving Office Technology and Management work performance, different organizations (companies, offices, hospitals etc) had Office Technology and Management expert that participated to the survey.

With the introduction of Database Management into the offices, the office technology and management graduate are required to perform their jobs faster and easier, handle varieties of tasks, communicate and store information etc. Despite the problem facing office technology graduate and it effect on their performance, Database Management can also enhance their work performance in organizations, eliminate fine wastage on task ensure security of documents and help them meet with the demand in the office.

\section{Recommendation}

The following recommendation is made from this study

1) The use of Database Management System should be introduced to all offices and department of an organizations in order to enhance the work performance 


\section{International Journal of Science and Research (IJSR) \\ ISSN (Online): 2319-7064}

Index Copernicus Value (2015): 78.96 | Impact Factor (2015): 6.391

of Office Technology and Management (OTM) graduates.

2) Employee should endeavor to replace the existing manual equipment with state of act equipment so as to effectiveness and efficiency of the office technology graduate.

3) Institution of higher learning and department of office technology and management (OTM) should strive to train their student effectively using Database management.

4) Office technology graduate undergoing training or working should be prepared to go for further training when the need arises in over to give the student the opportunity to acquire the skills of information and communication technologies.

5) Organization should ensure that the office technology graduate are trained and retrained from time to time toward the application of information and communication technologies to their job schedule in order to enhance their performance and productivity

6) It is suggested that further study should be conducted on several organizations

7) Further research should be carried out on this work so that necessary improvements can be made.

\section{References}

[1] Anigbogu, G. (2000). Systematic Planning for Educational Change.California: Mayfield publishing Company.

[2] Chimezie F. (2000). "Use of local area networks in schools. ERIC Digest." Syracuse, NY: ERIC Clearinghouse on Information Resources.

[3] John F. Roddick Advanced Computing Research Centre School of Computer and Information Science University of South AustraliaThe Levels, SA 5095, Australia.

[4] Ejeka Charles A. (2015) journal_Published by European Centre for Research Training and Development UK (www.eajournals.org).

[5] Iwhiwhu E.B. (2005). The Feature of Records Management in Nigeria. The Nigerian Archivist. Journal of the society of Nigerian Archivists 1(2\$3).

[6] Dr. Robert A. Esene, (2015) British Journal of Education Published by European Centre for Research Training and DevelopmentUK (www.eajournals.org).

[7] Ekula, I. O. (2010). Repackaging secretarial/office education curriculum towards achieving the objectives of vision 20:20:20. Journal of Vocational and Technical Education ABU Zaria 5(1).

[8] Esene, R. A. (2011). Evaluation of the NBTE new office technology and management curriculum for Nigerian Polytechnics: an analysis of entrepreneurship development. Business Education Journal 8(1).

[9] VitalisO.gode (2014). Journal of emerging trends in computing and information sciences www.cisjournal.org vol. 5, no12.

[10] FranklingWabwoba (2011). International journal of information and communication technology research www.esjournals.org vol. 1 no. 7.

[11]IJAAR-SSE [INTERNATIONAL JOURNAL OF ADVANCED ACADEMIC RESEARCH | Social
Sciences And Education] International Journal of Advanced Academic Research | www.ijaar.org.

[12] Asian Journal of Management Sciences\& Education Vol. 3(4) October 2014Leena and Luna International, Oyama, Japan. Copyright (C) 2014.

[13] Journal of Educational Policy and Entrepreneurial Research (JEPER) ISSN: 2408-770X (Print), ISSN: 2408-6231 (Online) Vol.2, N0.10. 2015. Pp 75-88 http://www.ztjournals.com/index.php/JEPER Okolocha and Ihionkhan. 